\title{
A Review of Some Positive Aspects of COVID-19 Pandemic
}

\author{
Aishwarya Rajesh Kothari \\ Intern, Department of Community Medicine, Jawaharlal Nehru Medical College, Datta Meghe Institute of \\ Medical Sciences (Deemed to be University), Sawangi (Meghe), Wardha-442001, Maharashtra. \\ Email: aishu9730@gmail.com \\ Type of article- Review article \\ Funding-DMIMS, Wardha
}

\begin{abstract}
The novel corona is keeping people indoors due to the increasing fear and mass confusion, it indeed has affected both the physical as well as mental health. We have been in the lockdown for over 4 months now and majority of us are knackered with the prolonged countrywide lockdown. Life has changed in months and beyond recognition. The virus has not only taken lives globally but also has given an unprecedented shock to the Indian economy. The magnitude of the economic impact depends on the duration of the lockdown, severity of the health issues and the manner in which the situation unfolds once the lockdown is lifted.The above mentioned reasons are sufficient enough for a mental breakdown but if look closely, Despite all the obvious hardships, we've shown incredible resilience.

During this period of lockdown everybody has started to live a different lifestyle which we could not imagine doing if given a choice.From doing all the household work at one side and balancing work life on other hand.We all come to know how to balance a personal and professional live on a lever of work from home. A new concept of ONLINE STUDIES has become familiar to each and everyone.Even though the pandemic has taken lives of thousands but it has also taught us a more broad spectrum way of looking at world and a way of living also.So in a nutshell there are a lots of things which happened for betterment of human lives and for mother earth as well. As it is said in course of time only the best will survive, this period of pandemic and lockdown was a very demanding and challenging time so only the best will survive. This apparent immortal pandemic has affected mental health to a level that all of us have actually ghosted the brighter side of it ,like the most obvious rationale for a lockdown is that the lockdown will contain and hopefully reduce the number of Covid-19 infections, and possibly give enough time to infected patients to recuperate ,Besides this there are various other positive effects that we as humans haven't paid attention towards Following are a few unseen positive effects of the Covid 19.
\end{abstract}

KEYWORDS: Positive impact, air and water quality,road traffic accidents, mental health

\section{Air Quality}

extremely toxic for one's respiratory . WHO's data released in the mid of 2018 showed that Before the nationwide lockdown due to the pandemic the air was considered 9 out of 10 people breathe highly polluted air which lead to an estimated concerning death toll of 7 million people every year due to highly polluted air[1].

All types of factories, transportation, and people's daily life abruptly stopped, perhaps for the first time, resulting in reduction the number of cars on the road, cancellation of trains and flights leading to falling of air pollution drastically. Mainly, studies have calculated nitrogen oxide to be the one of the major air pollutants and human activity is almost entirely responsible for the emission of nitrogen oxide in city regions, with on road vehicular transport being the number one cause. Given this it's not surprising that due to the strict global lockdowns, the level of nitrogen oxide has dropped a lot in city areas, especially in India's highlycrowded cities[2].

Numerous researchers have forecasted that the decrease in air pollution may now save lives, not only by decreasing susceptibility to covid-19 but also by preventing some of the world's seven million yearly fatalitiesbecause of air pollution. On the $2^{\text {nd }}$ and $4^{\text {th }}$ day of lockdown the country had 
seen $40 \%$ to $50 \%$ improvement in air quality .New Delhi was known to be the most polluted city in the world.The air quality index in New Delhi was 200 which is $25 \%$ above the unsafe level as deemed by WHO but as the cars were taken off the road and factories \& construction was at halt the air quality index has regularly fallen below 20.The middle and the eastern regions of Delhi have experienced highest improvement in air quality. With the decrease of air pollution in Agra due to the reduced vehicles Taj Mahal looks much more beautiful in cleaner air. The locals of Kathmandu witnessed the Mt Everest 200 $\mathrm{km}$ away from their valley. The well- known Silk Board Junction, known for the bad traffic jams in Bengaluru, is empty due to the lockdown. People in Punjab finally after 30 years can see Himalayan ranges from 100 miles away due to the reduced air pollution. Due to the large decrease in airplane emissions, the ozone layer is recovering to a great extent .The skies are piercing blue and even the birdsong seems louder than usual .The healing shown by nature during lockdown, there is no harm in utilizing lockdown as a possible emergency measure to fight severe air pollutions in future dates.[3]

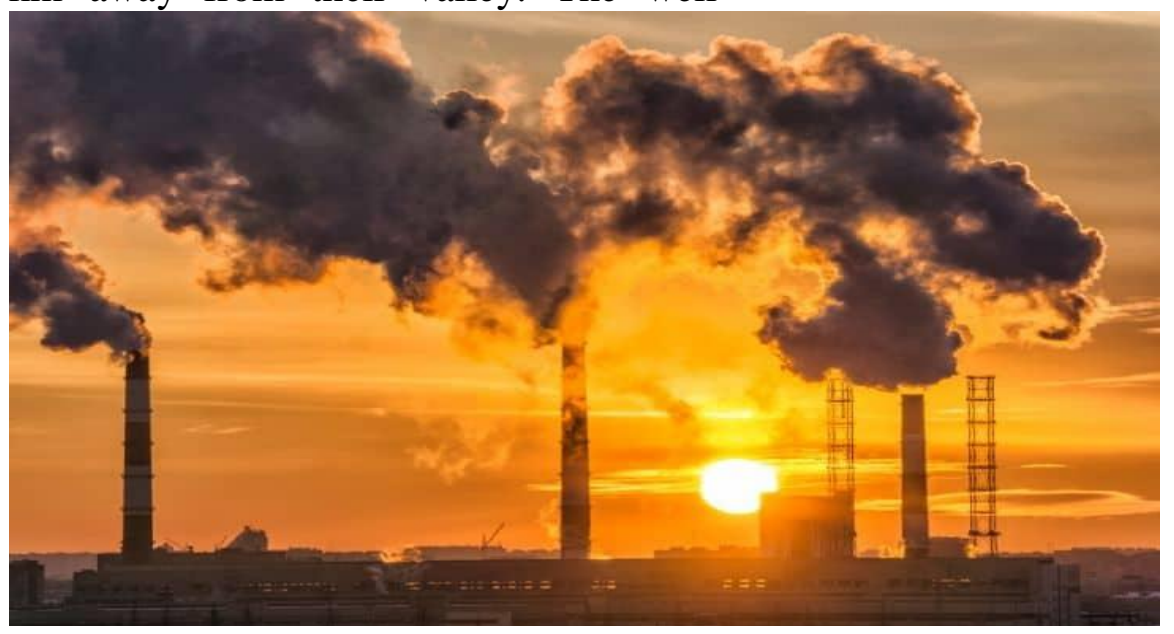

\section{Water quality}

The countrywide lockdown was imposed on $25^{\text {th }}$ March 2020 by the Prime Minister, and under 10 days, signs of betterment in water quality started emerging. Experts in multiple number have made a comparative study of various water bodies before and after the lockdown through the analysis of data generated from 36 real time water quality monitoring systems. Of thethirty six monitoring units placed, water quality at twenty seven points was found highly suitable for household purposes and reproduction of wildlife and fisheries in the lockdown period.In the lockdown time the main industries located near the water location emitting harmful water effluents that harmwater based ecosystems, such as industrial disposal of wastewater, crude oil, heavy metals, and plastics, have reduced or fully stopped. Hence, the level of pollution is estimated to be decreased and dissolved oxygen level in water has increased too.As the lockdown continues the water quality has improved significantly of the Yamuna River and ganga river as the people are indoors keeping ganga and Yamuna ghats deserted.Swans can now be again seen in Venice Canals. There has been a 40-50 per cent betterment in the quality of water of the Ganga and Yamuna rivers and hence it's finally now fit for drinking after necessary treatment.Businesses have a majoreffect on the water quality and therefore the lockdown due to the COVID19 spread has significantly increased water quality[4].

In a rare sighting, fishes can be seen near the Varanasi ghat steps. Critically 
endangered, south Asian dolphins called as the Ganges dolphins have been seen back in the Ganga river after roughlythirty years.This seems to have happened due to the absence of crowds and presence of clean water.After considering the noticeable changes post lockdown one can surely say that If you let nature be on its own, it persists and comes alive..[5]

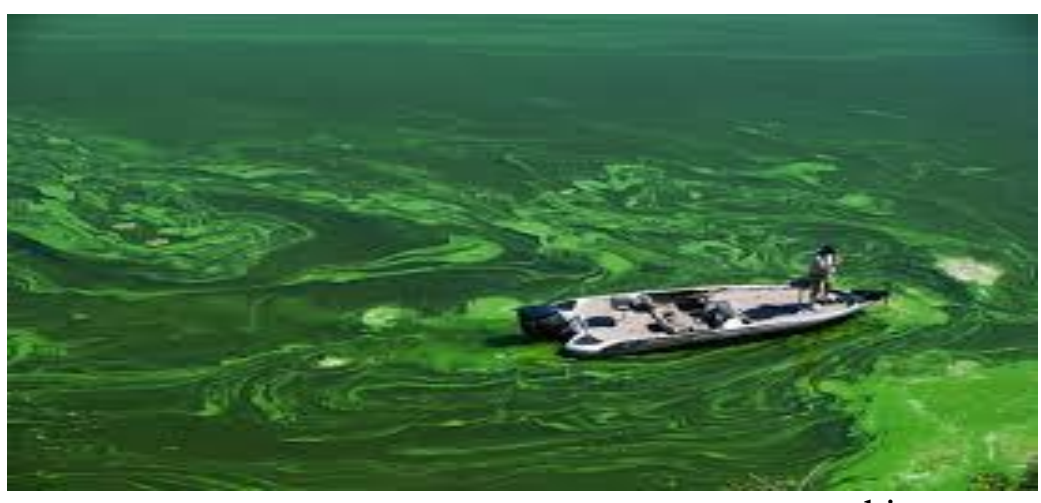

\section{Reduced road accidents}

The benefits of reduced transport are enormous and profound.The reduction in transport led to decrease in traffic accidents, wounds and mortalities which is a silver lining for people who are staying indoors and who are affected by the pandemic.The experts found that the state's reduction in accidents were due to reduction of up to 55 percent of traffic and a forty to fifty\%reduction in serious wounds for drivers, walkers and bicyclists. According to Road traffic office data,

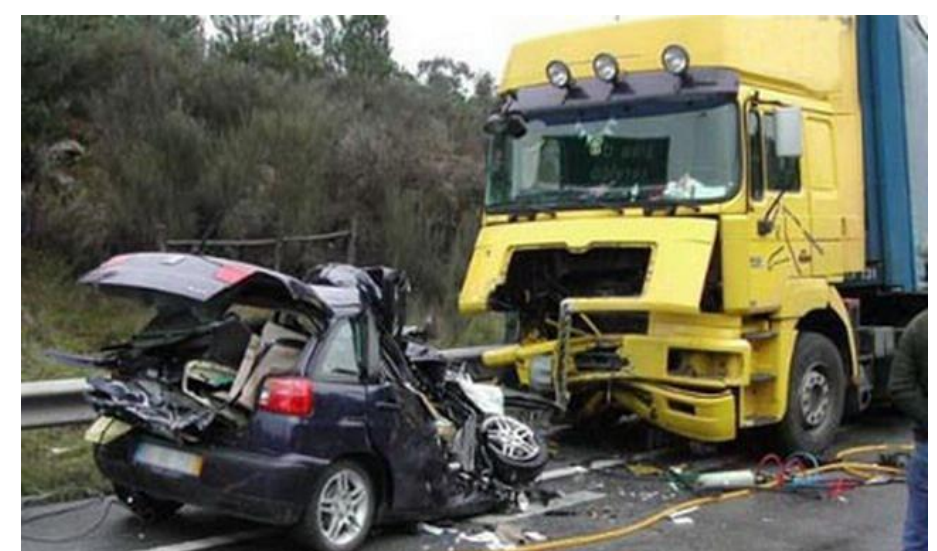

\section{Reduced communicable diseases}

Lockdowns and social distancing measures restrain the movement of people aiming at slowing the spread of corona virus but it thirteen people died in ninety four RTA cases in Mumbai in March 2020, in comparison to fortyfatalities in two fifty eight accidents during March 2019 and due to the lockdown the rate of car accidents have witnessed a dramatic fall in number hence the mortality rate due to car accidents have reduced too.[6]Reduced road accidents also reduced a burden on hospital casualties so that doctors can focus there attention on the treatment of positive patients of Covid.

also helped in reducing the transit of other communicable diseases or flu. Worldwide roughly 290,000-650,000 people die from seasonal flu, so a decreased flu season could mean thousands of lives are saved. The seasonal flu are usually at a peak in 
the month of February and are reduced in the month of May 2020but this year the lab has given confirmation of reduction in the number of cases reported. In the month of January, before the coronavirus, the flu season was about toto be the most severe in ten years. The flu season came to an end soon despite the fact that it started severely. In Hong Kong, compared with previous years, the number of chickenpox cases dropped by about fifty percent of the actual number of cases .[9] People got to know that deadly diseases can be prevented by simple precautions like wearing mask ,keeping social distance,frequent hand washing.Thishabit of taking precaution so that disease should not spread will be very much usefull in long term for controlling diseases like influenza and tuberculosis. [7]

Pandemic gave birds and animals a reason to cheer!

Reduced human movement and hence the interference has resulted in less disturbance to migratory birds prompting them to stay longer. Ten thousand flamingos have collected in the city of New Mumbai. The birds usually come to thisregionannually, as per experts report they have seen a high level of increase in their population this year. In the absence of functions and marriages the noise pollution has fallen to a considerable level which has also benefited the birds.Due to reduced traffic animals can now freely move and the ones caged are happier in the absence of human presence, some of the birds and animals become more playful in the absence of humans around them[8].Improved hygiene habits

According to a research report surveying habits of people during the coronavirus pandemic and subsequent lockdowns, people are giving more attention to hygienic conditions in their kitchens and personalactivities. $70 \%$ of participating people in the survey told that they werecleaning their hands more often and/or for longer timeprecedingwork in the kitchen and sixty five \% percent did this before eating. People have been usingsanitizers more frequently which leads to reduction in other communicable diseases. Experts have showed hope thatthese positive health practices will go on even after the crisis as better hygiene could mean fewer food borne infections. During the lockdown period it was made compulsion to wear mask in public places like supermarkets this habit of wearing mask will be very much impactful in controlling the transfer of diseases like tuberculosis[9].

\section{Healthier versions of ourselves}

We may be missing out on the fun we had at dinners with our close ones but we are all fueling ourselves with something healthy now.Besides eating healthy we are focusing on physical health by continuing to exercise at home or develop new workout regimes which can be contributing to our mental health too. The more free time and the concern for obesity has motivated a lot ofindividuals to start exercising at their home. Since there is no domestic help available sweeping of floors, mopping, dusting, and cleaning cobwebs by oneself are methods to exercise.The few wise people used the captive time to develop mindfulness and wisdom withMeditation. Apart from the benefits mentioned above people now have time for sufficient sleep which we couldn't manage pre-lockdown. The most important factor is that we now have discovered our personalized version of 'me time'. This is an opportunity to reset the body clocks and do away with the bad lifestyle before the end of the lockdown. Because of the life everybody was living somehow the priority of health first was fading and sedentary lifestyle was very much common but this pandemic once again reinforced the importance of having a 
active and healthy life. The circadian rhythm was disturbed in the fast and furious lifestyle which was once again set on time in this lockdown period.

Early to bed and early to wake up was the concept in ancient India but in modern life style it was not possible to follow this. But since there was a slowdown of lives in lockdown this concept once again came into picture.

Most of people have not seen early sunrise in their entire live but this pandemic gave an opportunity to enjoy the sunrise and sunsets with family which no doubt helped to strengthen the bonds between family members.[10]

\section{Behavioral Changes}

This pandemic is an abnormal situation faced by everyone globally therefore some abnormal behavior change has to be considered normal. Some people forced themselves into mental breakdowns,anxieties and solitude while a lot of them took it positively as an opportunity to slow down the life and learn the art of living,meditating, focusing on oneself and enjoying quality time with family. The sale in the sin goods has also faced a drastic fall which depicts that smoking doesn't form a part of life of majority people. Experts believe that there won't an average effect of changes incorporated for months but there will be trend set in the change seen in people[11]

While in lockdown, introverts have been able to avoid the social pressure for interaction while the extroverts could socialize through social media.Individuals have given more time in staying home and taking care of themselves and theirhomes. They increased reading time, learned how to cook, focus on their habits, solve puzzles or exercise. Some of them have tidied their houses properlyand taken care of that waste they were hoping to throw away for ages now. People now are getting more individualistic than ever before
They focus more on the soul and not on the physical appearance since they are less concerned about the peer pressure as they meet lesserpeople. The lockdown has transformed people into law-abiding citizens, which was usually a challenging task to bring into action for law enforcers across the country.

The stereotype in community that females should stay indoor have been changed because of this lockdown. This lockdown made everyone stay indoor irrespective of their profession and gender.

This lockdown was a opportunity for males to have a close look howIndianfemales especially married one manages there daily life in such a perfect way so they also deserve equal respect as that of someone who is working outdoor and earning.

All the childhood memories of playing board games, watching movies together, having lunches and dinners together was relived once more[12]

Students who have been away from home for many years got the opportunity to spend some time with their families and friends this some way or other implicated the importance of family in behavior of students.

\section{Crime incidents have become rarer}

The crime rate in the entire world has plummeted in the last few months as COVID-19 has paralyzed the entire globe.A sharp fall of $42 \%$ in the crime rates has been witnessed by the Delhi police in the capital of the country.A similar drop in the crime rates has been witnessed in Chennai, Mumbai and Kolkata. Since families stayed together and houses were not closed it also provided a safe environment.

\section{Falling prices of fuels}

Where all major transportation have been stopped to control the spread of corona virus, private vehicles have been a rare sight. Since the demand for the fuel has 
fallen drastically the prices of fuel are expected to fall in the near future. This also contributed in betterment of environment.[13]

\section{Psychological changes}

The lockdown has positive spin-offs in heightening emotional connection with strangers and sense of community. In our attempts to cope with the new way of living we are unknowingly changing the blueprints for how we live our lives in near future. The lockdown has taught humanity to live a minimalistic life, thereby putting less burden on nature and climate. The changes in lifestyle and behavior have given humanity time to think how people would like to live in a post-coronavirus world .We now have a strong urge to spend time in physical proximity with each other, Meeting with friends, walking in a park or going to a restaurant these things seem special again and we have started taking things less as granted ,this comes as no surprise as the proverb goes "birds of a feather flock together".

Coronavirus is presenting society with a formidable common enemy which doesn't distinguish between reds and blues, and when faced with a common threat a shared sense of togetherness can lead us to look past their differences and collectively face the challenge.[14]

In the absence of domestic help we now realize that it is actually possible to take care of all the household chores by ourselves and men in the house now have developed immense respect for the women of the house after getting acquainted with the amount of work actually takes care of In the day today life.[15]

People have now realized that our true needs are quite simple and they can function quite effectively with the bare minimum. The union government has allowed weddings to be conducted with the catch that there will be $\max 50$ people attending it Also, max 20 people can attend a funeral which is a bewildering step taken to maintain minimum human contact and cut down on unnecessary expenditures. Likewise majority of us have succumb on the goods which are excessive in the slightest of ways.[16]

So by far we know that not commuting has its own set of benefits, maybe most of us are working from home when technology allows .The reduction in the movement of people will give us cleaner air when we finally go out. Most of us might even end up take up bicycles for transport post lockdown.[17]

The pandemic also gave us lifelong lessons of not taking people distant from us for granted. The undeniable benefit of the pandemic is that it showed us a better future that we all want to embrace. It gave us a preview of an environment that we all aspire to live in. The environment where we see mother nature breathe again.COVID-19 doesn't differentiate in the race, caste, creed, gender, language and color before striking hence it is wise to focus on the brighter side of the pandemic and overcoming the negative one. We as humans must fight this battle with unity and brotherhood. We are much stronger than this, we together can outrun this pandemic. So gird up your lions we are in this together. In Indian society it is a concept that wedding or any other functions in family cannot be held without thousands of people but this psychology has been changed during the pandemic of Covid. Since there was ban on social gatherings government permitted only 50 members to be present in any ceremony which not only reduced the financial burden on the brides family but also decreased the wastage of food which usually happens in Indian weddings.[18] Many studies on Positive aspects of Covid pandemic were reported[19-24]. Studies on indigenous aspects of Covid related positive outcomes are available [25-29]. 


\section{CONCLUSION}

Even though the covid 19 has created very ill effect on human health but at the same time if we look at a positive side we will understand that there are few thing which this corona pandemic has done on human life and behavior which we would have never achieved if this pandemic had not been there.

There are many good things we achieved like improved air and water quality, decreased rates of road traffic accidents, reduced transmission of communicable diseases, increased family values. The pandemic also gave us lifelong lessons of not taking people distant from us for granted. The undeniable benefit of the pandemic is that it showed us a better future that we all want to embrace. It gave us a preview of an environment that we all aspire to live in. The environment

creed, gender, language and color before striking hence it is wise to focus on the brighter side of the pandemic and overcoming the negative one. We as humans must fight this battle with unity and brotherhood. We are much stronger than this, we together can outrun this pandemic. So gird up your lions we are in this

together.

\section{References-}

1. MeenaSegha - covid-19 lockdown positive consequences for air quality- economics time, April/20/2020

2. Sulaman Muhammad- covvid-19 pandemic and environment pollution: A blessing in disguise?, 17/4/2020

3. James Poetzscher-the effect of covid -19 on India's air quality, Business line, May12,2020

4. Lokhandwala, S. and Gautam, P., 2020. Indirect impact of COVID19 on environment: A brief study in Indian context. Environmental research, 188, p.109807.
5. Ghani AC, Donnelly CA, Cox DR, Griffin JT, Fraser C, Lam TH, Ho LM, Chan WS, Anderson RM, Hedley AJ, Leung GM. Methods for estimating the case fatality ratio for a novel, emerging infectious disease. American journal of epidemiology. $2005 \quad$ Sep 1;162(5):479-86.

6. SnehaGautamDonkelaar AV, Martin RV, Brauer M et al (2010) Global estimates of ambient fine particulate matter concentrations from satellite-based aerosol optical depth: development and application. Environ Health Perspect 118(6):847

7. Lai C.C., Shih T.P., Ko W.C., Tang H.J., Hsueh P.R. Severe acute respiratory syndrome coronavirus 2 (SARS-CoV-2) and coronavirus disease-2019 (COVID-19): the epidemic and the challenges. Int $\mathbf{J}$ Antimicrobials

Agents. 2020;55:105924.

8. Rubin GJ, Wessely S. The psychological effects of quarantining a city. Bmj. 2020 Jan $28 ; 368$.

9. Al Najjar, N. S., Attar, L. M., Farahat, F. M., and Al Thaqafi, A. (2016). Psychobehavioural responses to the 2014 Middle East respiratory syndrome-novel corona virus [1MERSCoV]1 among adults in two shopping malls in Jeddah, western Saudi Arabia. East. Mediterr. Health J. 221, 817-823.

10. Al-Tawfiq JA, Al-Homoud AH, Memish ZA. Remdesivir as a possible therapeutic option for the COVID-19. Travel medicine and infectious disease. 2020 Mar 5.

11. Nelson B, Pettitt AK, Flannery J, Allen N. Psychological and Epidemiological Predictors of COVID-19 Concern and HealthRelated Behaviors. 
12. Mohammed A, Sheikh TL, Poggensee G, Nguku P, Olayinka A, Ohuabunwo C, et al. Mental health in emergency response: lessons from Ebola. Lancet Psychiatry (2015) 2(11):955-7. .

13. Ghani AC, Donnelly CA, Cox DR, Griffin JT, Fraser C, Lam TH, Ho LM, Chan WS, Anderson RM, Hedley AJ, Leung GM (2005) Methods for estimating the case fatality ratio for a novel, emerging infectious disease. Am J Epidemiol 162(5):479-486.

14. Neetu Chandra Sharma- Doctors, nurses face stigma over coronavirus, asked to vacate rented homes- 25 March 2020https://www.livemint.com/news/in dia/doctors-nursesface-stigmaover-coronavirus-asked-to-vacaterented-homes11585074366997.html

15. K. karunatilake- positive and negative impacts of COVID-19, an analysis with special reference to challenges on the supply chain in South Asian countries- Journal of science and development 2020

\section{I.Khan,S.Shah-COVID-19}

pandemic and its positive impacts on environment: an updated review-International journal of science and technology 2020

17. Economist. Building up the pillars of state [briefing]. The Economist, March 28th 2020

18. BasavrajNagoba,SohanshelkarPositive aspects, negative aspects and limitations of plasma therapy with special reference to COVID19-Journal of infection and public health.

19. https://www.sciencedirect.com/scie nce/journal/1876034166.
20. AnjankarAshish, $\quad$ P., $\quad$ P. AnjankarVaibhav, J. Anjankar Anil, and K. Lata. "Positive Aspects of Covid 19 Pandemic: A Blessing in Disguise." International Journal of Research in Pharmaceutical Sciences 11, no. Special Issue 1 (2020): 187-91. https://doi.org/10.26452/ijrps.v11iS PL1.2371.

21. Borage, S., and P. Shelotkar. "Positive Effects of Covid-19 on Earth." International Journal of Research in Pharmaceutical Sciences 11, no. Special Issue 1 (2020): 234-38. https://doi.org/10.26452/ijrps.v11iS PL1.2704.

22. Kamdi, P.S., and M.S. Deogade. "The Hidden Positive Effects of Covid-19 Pandemic." International Journal of Research in Pharmaceutical Sciences 11, no. Special Issue 1 (2020): 276-79. https://doi.org/10.26452/ijrps.v11iS PL1.2712.

23. Srivastava, R., N. Rathi, N. Thosar, S. Baliga, M. Khubchandani, V. Mohite, J. Mehta, and R. Waykar. "Contemporary Treatment Modalities for the Management of SARS-CoV-2 Positive Patients: An Overview." International Journal of Research in Pharmaceutical Sciences 11, no. Special Issue 1 (2020): 839-46. https://doi.org/10.26452/ijrps.v11iS PL1.3090.

24. Budhrani, A.B. "A Review: Coronavirus, Its Types, and Impact of Covid-19 on Global Wealth." International Journal of Research in Pharmaceutical Sciences 11, no. Special Issue 1 (2020): 455-61. https://doi.org/10.26452/ijrps.v11iS PL1.2811.

25. Kothari, L., S. Wadatkar, R. Taori, P. Bajaj, and D. Agrawal. "Coronavirus: Towards Controlling 
of the Pandemic-Indian Scenario." International Journal of Research in Pharmaceutical Sciences 11, no. Special Issue 1 (2020): 462-68. https://doi.org/10.26452/ijrps.v11iS PL1.2813.

26. Lohiya, S.B., S. Damke, and R. Chaudhary. "Coronavirus Disease (COVID) 2019 in Children - A Short Review." International Journal of Current Research and Review 12, no. 17 (2020): 172-77. https://doi.org/10.31782/IJCRR.20 20.121726.

27. Parwe, S.D., M.A. Nisargandha, and R. Thakre. "Role of Convalescent Plasma Therapy in New Coronavirus Disease (Ncovid19): A Review." International Journal of Research in Pharmaceutical Sciences 11, no. Special Issue 1 (2020): 546-49. https://doi.org/10.26452/ijrps.v11iS PL1.2846.

28. Rathi Saurabh, D., P. Nikhade, N. Motwani, S. Baror, and A. Jaiswal. "Coronavirus Pandemic-the Real Lessons Are Learnt in the Time of Crises." International Journal of Research in Pharmaceutical Sciences 11, no. Special Issue 1 (2020): 1011-14. https://doi.org/10.26452/ijrps.v11iS PL1.3426.

29. Darwate, T., and S. Hiware. "Concept of Rasayana Therapy in Covid 19." International Journal of Research in Pharmaceutical Sciences 11, no. Special Issue 1 (2020): 857-61. https://doi.org/10.26452/ijrps.v11iS PL1.3093. 